
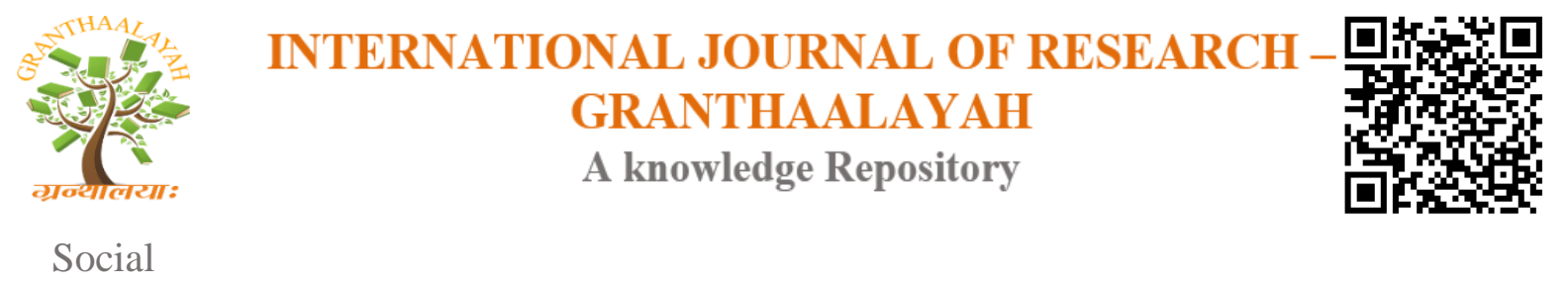

\title{
DIGITAL GAMES - A MAGICAL LEARNING TOOL FOR SLOW LEARNERS
}

\author{
Dr. Paul Albert. A *1 \\ ${ }^{* 1}$ Assistant Professor, Immaculate College of Education for Women, Puducherry, India
}

\begin{abstract}
The present article mainly focused on how digital or computer games act as a fruitful learning tool for slow learners through game based learning. Also, it describes that among many learning methods, game based learning is a suitable way using digital games for slow learners especially for digital natives. In addition, the present article highlighted the educational benefits and effectiveness of digital games. Further, it explores some digital games that can be used in the educational context. Finally the present article suggested that the digital games can be used as a tool in teaching and learning process for slow learners.
\end{abstract}

Keywords: Slow Learners; Digital Natives; Multi Player Games; Digital Games; Cognitive Skills; Online Games.

Cite This Article: Dr. Paul Albert. A. (2018). "DIGITAL GAMES - A MAGICAL LEARNING TOOL FOR SLOW LEARNERS.” International Journal of Research - Granthaalayah, 6(5), 407-412. https://doi.org/10.29121/granthaalayah.v6.i5.2018.1468.

\section{Introduction}

In the field of education, most of the researchers and educationists focused to a particular problem. It is a topic which has been discussed over the decades, i.e 'Slow Learners'. Who are slow learners? There is some misconception with learning disability. Many researchers tried to state clear idea about slow learners. Borah (2013), described that students who are below average in intellectual capacities whom we cannot term as disabled are called slow learners. In addition, Malik (2009), pointed out the slow learners are children who are doing poor performance in schools, yet are not eligible for special education. They are lacked in concentration, retention and abstract thinking with their age group. Further, Qian (2008), define the term slow learner is the group of students who learn more slowly than their peers, yet do not have a disability requiring special education. In short, slow learners are normal students but the problem is that they are simply not interested in studying under traditional system of education.

In general playing games are most intentional, pleasurable and interesting activities to children particularly to develop physical health as well as mental health. Games can be defined as a form of play with goals and structure (Maroney, 2001). Games seem to put the learner in order to meet 
harder challenges and this kind of learning is accomplished through trial and error (Gee, 2003). In addition, games are supporting to active learning, experiential learning and problem based learning (Oblinger, 2004). Additionally, games can promote motivation, engagement and learning (Gillern, and Alaswad, 2016). Further, games can increase the students' interest and confidence level (Paraskeva, Mysirlaki, and Papagianni, 2010). Most importantly, Bruner, (1960) said that the pace of the game activities can be adjusted for faster or slower learners, novices or experts (as sited in Paraskeva, Mysirlaki, and Papagianni, (2010). Hence the present article tried to examine the potential of digital games as educational tools for slow learners.

\section{Game Based Learning: A New Trend in Education}

Nowadays technological developments provide new and more enriching gaming experiences to the people. Especially digital games or computer games are more popular among younger generations which can be termed as 'digital natives' by Prensky, (2001) (as sited in Simoes, Redondo, and Vilas, 2012), 'gamer generation' (Beck, and Wade, 2006) or the 'net generation' (Tapscott, 1998). Digital games are just software applications running on a personal computer or mobile devices. Digital games also took advantage of augmented reality technologies to become more enjoyable and enhanced user interfaces with new ways of interacting with the players. Similarly digital games are making the users to be addicted to play instantly. For instance, mobile games in smart phones or tablets like Angry birds, Temple run, Candy Crush Soda etc., have an increasingly a large number of users in all ages in which they involve in a great amount of time to play these games (Simoes, Redondo, and Vilas, 2012). Thus digital games have been proposed as a potential tool in teaching and learning by researchers (Barab, et.al. 2005: Gee, 2003).

The use of digital games as learning tool is called game based learning that has been gaining prominence in recent decades. Game based learning is thought to be an effective tool for learning (Kebritchi, and Hirumi, 2008; Saridaki, M., Gouscos, D., and Meimaris, M., 2008; Papastergiou, 2009; Furio, et.al. 2013; Dominguez, et.al. 2013). Game based learning can be defined as the use of a computer game based approach to deliver, support, and enhance teaching, learning, assessment, and evaluation (Connolly, Stansfield, and Hainey, 2007). Computer games could develop number of skills such as decision making, cooperation, cognitive skills and problem solving (Robertson, and Howells, 2008; Ebner, and Holzinger, 2007). In addition digital games could produce a superior learning experience to the students (Carenys, Moya, and Perramon, 2016). Also, a study indicated that not only playing games but also creating educational computer games and development activities enabled active experiencing of subject content for middle school students and engaged them in thinking (Ke, 2014).

\section{Multiplayer Online Games}

Recently online games that draw together players from all over the world to dominate the digital entertainment and to become fanatic particularly for children and adolescents. It seems that multiplayer games have noticeable learning potential and studies have also focused on the types of learning which could be supported by these games (Herz, 2001). The important benefit of multiplayer online games is that the interaction enables players to communicate and collaborate with each other in the game sessions (Manninen, 2003). Further a study suggested that multiplayer online games make the learners being interesting enough to engage by integrating elements that 
limit play sessions and oblige players to actively engage in an external educational task before continuing play, ideally in collaboration with other players (Paraskeva, Mysirlaki, and Papagianni, 2010).

\section{Effectiveness of Digital Games}

Many research studies confirmed that games have positive effect on students' performance. For instance, a study reported that interactive games were more effective than traditional classroom instruction on learners' academic learning and cognitive skill development (Vogel, GreenwoodEricksen, Cannon-Bowers, and Bowers, 2006; Vogel, et.al. 2006). In addition, a study found that elementary and middle school students gained learning through digital games. It was also found that playing games contributed to science knowledge retention (Clark, Nelson, Sengupta, and D'Angelo, 2009). A related investigation compared students with high in game performance to students with low in game performance. It revealed that there is a significant difference in learning gains, engagement and game play behaviours (Rowe, Shores, Mott, and Lester, 2010).

Other studies have reported that game playing resulted in improved academic achievement of the students (Gillispie, Martin, and Parker, 2009; Hickey, Ingram-Goble, and Jameson, 2009; Papastergiou, 2009). To support these results, one more study reported that significant learning is gained from the serious game (Tuzun, et.al. 2009). Similar conclusion were found in another study, which reported that playing 3-D digital games positively impact on students' math learning and achievement (Gillispie, Martin, and Parker, 2009). Likely, in other study it was proved that the game based mobile learning improved the students' math performance in India (Kim, et.al. 2012). Further, the results of a study showed that the participants who used the gesture interactive game based learning approach demonstrated better learning performance and motor skills (Hsiao, and Chen, 2016).

\section{Digital Games for Learning}

Many researchers proposed and used a number of digital games in their research studies to engage the students in learning. For instance, Rosas, et.al (2003) presented a software application that contained five games with the objective of evaluating the effects of video-games on students' language acquisition skills and mathematical operations. Likewise, Ebner and Holzinger (2007), designed an online computer game for teaching civil engineering to university students.

In addition, 'Astra Eagle' is the web based game used in a study to reinforce academic standards for mathematics. This game improves a variety of math skills, such as measurement, comparing whole numbers, solving simple equations and mapping $\mathrm{X}$ and $\mathrm{Y}$ coordinates (Ke, 2014).

As emerging digital games, gesture interactive games have opened new opportunities for learning. Gesture interactive game based learning helps the students to reinforce their memories, comprehend learning materials, improve their learning performance and strengthen their motor skills in a student centered context in which learners are actively engaged (Altanis, Boloudakis, Retalis, and Nikou, 2013; Huang, Liu, Kao, and Huang, 2009; Li, Wang, Wu, and Chen, 2014). For instance, 'The Goalkeeper' is a gesture interactive game which is used in a study to improve students' learning performance and motor skills (Hsiao, and Chen, 2016). 


\section{Conclusion}

Slow is not just a four letter word when used in conjunction with the word learner. It is a concept related to time or speed. Cautiousness, thoroughness, meticulousness, reflectiveness, and an emphasis on the concrete are often commendable assets of the slow learner (Humphrey, and Sullivan, 1970). The fundamental task of education is to help the normal children achieve their potential and desired growth (Mami, and Arayesh, 2010). Similarly, digital games are helping the slow learners to achieve like normal one. In addition, Humphrey, and Sullivan, (1970), illustrated that the slow learners can learn concepts and academic skills more quickly and with greater retention by participating in pleasurable active games than by learning in traditional ways. To support this, an experimental study proved that the fast and slow learners forgetting curves were parallel i.e. they have same retention power (Gentile, et.al, 1982). Likewise, in another study, it provided evidence that, when proper gaming procedures are used retarded individuals can be equated with normal in learning, with the same retention results (Cappella, 1981). Therefore with the points and evidences discussed in the present article it is anticipated that game based learning i.e digital games can be act as a magical learning tool for slow learners.

\section{References}

[1] Altanis, G., Boloudakis, M., Retalis, S., \& Nikou, N. Children with motor impairments play a Kinect learning game: first findings from a pilot case in an authentic classroom environment. Interaction Design and Architecture(s) Journal, 19, 2013, 91-104.

[2] Barab, S., Thomas, M., Dodge, T., Carteaux, R., \& Tuzun, H. (2005). Making learning fun: Quest Atlantis, a game without guns. Educational Technology Research \& Development, 53(1), 86-107.

[3] Beck, J. C., \& Wade, M. The kids are alright: How the gamer generation is changing the workplace. Boston: Harvard Business School Press, 2006.

[4] Borah, R., R. Slow learners: role of teachers and guardians in honing their hidden skills. International journal of educational planning and administration, 3(2), 2013, 139-144.

[5] Bruner, J. The process of education. New York: Vintage, 1960. In Paraskeva, F., Mysirlaki, S., and Papagianni, A. Multiplayer Online Games as Educational Tools: Facing New Challenges in Learning. Computers \& education, 54, 2010, 498-505.

[6] Cappella, B.J. Individual Difference in Immediate and Delayed Retention by Children in the IQ range 55 to 130. Unpublished Ph.D dissertation, department of educational psychology, state university of New York at Buffalo, 1981.

[7] Carenys, J., Moya, S., and Perramon, J. Is It Worth It to Consider Videogames in Accounting Education? A Comparison of a Simulation and a Videogame in Attributes, Motivation and Learning Outcomes. Revista de Contabilidad - Spanish Accounting Review. 2016, Retrieved from http://dx.doi.org/10.1016/j.rcsar.2016.07.003.

[8] Clark, D., Nelson, B. C., Sengupta, P., \& D’Angelo, C. Rethinking Science Learning Through Digital Games and Simulations: Genres, Examples, and Evidence. In National academies of sciences learning science: Computer games, simulations, and education conference, Washington, DC, 2009.

[9] Connolly, T. M., Stansfield, M. H., \& Hainey, T. An Application of Games-Based Learning within Software Engineering. British Journal of Educational Technology, 38(3), 2007, 416-428.

[10] De Scholz, H.C., and McDougall, D. Comparison of Potential Reinforcer Ratings between Slow Learners and Regular Students. Behaviour therapy, 9, 1978, 60-64.

[11] Dominguez, A., De-Navarrete, J.S., De-Marcos, L., Sanz, L.F., Pages, C., Javier, J., and Herraiz, M. Gamifying Learning Experiences: Practical Implications and Outcomes. Computers \& Education, 63, 2013, 380-392. 
[12] Ebner, M., \& Holzinger, A. Successful Implementation of User-Centered Game Based Learning in Higher Education: An Example from Civil Engineering. Computers \& Education, 49(3), 2007, 873-890.

[13] Furio, D., Gancedo, S.G., Juan, M.C., Segui, I., \& Rando, N. Evaluation of Learning Outcomes Using an Educational iphone Game vs Traditional Game. Computers \& Education, 64, 2013, 123.

[14] Gee, J. P. What games have to teach us about learning and literacy. New York: Palgrave Macmillan, 2003.

[15] Gee, J. P. What Video Games Have to Teach Us About Learning and Literacy. NY: Palgrave Macmillan, 2003.

[16] Gentile, R. J., Monaco, N., Ejiofor, I.E.I., Ndu, A. N., and Ogbonaya, P. K. Retention by 'Fast' and 'Slow' Learners. Intelligence, 6, 1982, 125-138.

[17] Gillispie, L., Martin, F., \& Parker, M. Effects of the Dimension-M 3D Video Gaming Experience on Middle School Student Achievement and Attitude in Mathematics. Proceedings of Society for Information Technology \& Teacher Education International Conference, 2009, 1462-1469.

[18] Hickey, D. T., Ingram-Goble, A. A., \& Jameson, E. M. Designing Assessments and Assessing Designs in Virtual Educational Environments. Journal of Science Education and Technology, 18(2), 2009, 187-208.

[19] Hsiao, H.S., and Chen, J.C. Using a Gesture Interactive Game Based Learning Approach to Improve Preschool Children's Learning Performance and Motor Skills. Computers \& Education, 95, 2016, 151-162.

[20] Huang, M. C., Liu, M. N., Kao, Y. H., \& Huang, S. C. The Physical Interactive Game Design for Autistic Children. Ergonomic Study, 10(2), 2009, 1-10.

[21] Humphrey, J.H., \& Sullivan, D.D. Teaching Slow Learners Through Active Games, Springfie!d, Ill., Charles C. Thomas, 184 pages, By Frances B. Cacha, C.W. Post College, Brookville, N .Y. 1970.

[22] Ke, F. An Implementation of Design Based Learning Through Creating Educational Computer Games: A Case Study on Mathematics Learning During Design and Computing. Computers \& Education, 73, 2014, 26-39.

[23] Kebritchi, M., \& Hirumi, A. Examining the Pedagogical Foundations of Modern Educational Computer Games. Computers \& Education, 51, 2008, 1729-1743.

[24] Kim, P., Buckner, E., Kim, H., Makany, T., Taleja, N., and Parikh, V. A Comparative Analysis of a Game Based Mobile Learning Model in Low Socio Economic Communities of India. International journal of educational development, 32, 2012, 329-340.

[25] Li, P. L., Wang, J. C., Wu, C. H., \& Chen, C. H. (2014). The Design of Motion-Sensing Computer Games Applying on the Physical Education Curriculum for Students with Special Needs. Special Education \& Assistive Technology, 10, 2014, 41-51.

[26] Malik, C. Effect of Intervention Training on Mental Abilities of Slow Learners. International journal of edu.sci, 1(1), 2009, 61-64.

[27] Mami, S., and Arayesh, B. Comparative Study of Educational Status and Behavioural Disorder between Slow Learner and Normal Students of Illam Province. Procedia-social and behavioural sciences, 5, 2010, 221-225.

[28] Manninen, T. Interaction Forms and Communicative Actions in Multiplayer Games. Game Studies: The International Journal of Computer Game Research, 3(1),2003, 5-10.

[29] Papastergiou, M. Digital Game-based Learning in High School Computer Science Education: Impact on Educational Effectiveness and Student Motivation. Computers \& Education, 52, 2009, $1-12$.

[30] Paraskeva, F., Mysirlaki, S., and Papagianni, A. Multiplayer Online Games as Educational Tools: Facing New Challenges in Learning. Computers \& Education, 54, 2010, 498-505. 
[31] Prensky, M. Digital-Game Based Learning. McGraw-Hill, 2001. In Simoes, J., Redondo, R.D., and Vilas, A., F. A Social Gamification Framework for a K-6 Learning Platform. Computers in human behaviour, 2012.

[32] Qian, J. English Classroom Interaction between Slow Learners and Teachers: A Case Study of Slow Learners at Primary Level. Master of philosophy dissertation, department of special needs education, faculty of education, university of Oslo, Norway, 2008.

[33] Robertson, J., \& Howells, C. Computer Game Design: Opportunities for Successful Learning. Computers \& Education, 50, 2008, 559-578.

[34] Rosas, R., Nussbaum, M., Cumsille, P., Marianov, V., Correa, M., Flores, P., et al. Beyond Nintendo: Design and Assessment of Educational Video Games for First and Second Grade Students. Computers \& Education, 40(1), 2003, 71-94.

[35] Rowe, J. P., Shores, L. R., Mott, B. W., \& Lester, J. C. Integrating Learning, Problem Solving, and Engagement in Narrative-Centered Learning Environments. International Journal of Artificial Intelligence in Education, 2010, 166-177.

[36] Saridaki, M., Gouscos, D., \& Meimaris, M., Digital Game-based Learning for Students with Mild Intellectual Disability: the EPINOISI project. Paper presented in the EUTIC conference, 2008. Retrieved from http://www2.media.uoa.gr/epinoisi/docs/papers/EUTIC 2008.pdf.

[37] Simoes, J., Redondo, R.D., and Vilas, A., F. A Social Gamification Framework for a K-6 Learning Platform. Computers in human behaviour, 2012. Retrieved from http://dx.doi.org/10.1016/j.chb.2012.06.007.

[38] Tapscott, D. Growing up Digital. The Rise of the Net Generation. New York: McGraw-Hill, 1998.

[39] Tuzun, H., Yilmaz-Soylu, M., Karakus, T., Inal, Y., \& Kizilkaya, G. The Effects of Computer Games on Primary School Students' Achievement and Motivation in Geography Learning. Computers \& Education, 52, 2009, 68-77.

[40] Vogel, J. J., Greenwood-Ericksen, A., Cannon-Bowers, J., \& Bowers, C. A. Using Virtual Reality with and without Gaming Attributes for Academic Achievement. Journal of Research on Technology in Education, 39, 2006, 105-118.

[41] Vogel, J. J., Vogel, D. S., Cannon-Bowers, J., Bowers, C. A., Muse, K., \& Wright, M. Computer Gaming and Interactive Simulations for Learning: A Meta-analysis. Journal of Educational Computing Research, 34(3), 2006, 229-243.

*Corresponding author.

E-mail address: albertphd1986@ gmail.com 